\title{
VPLIV IZOBRAŽEVANJA STAREJŠIH NA MOTIVACIJO ZA IZOBRAŽEVANJE OSTALIH GENERACI]
}

Prof. dr.

Ana Krajne

Filozofska fakulteta

Univerze $v$ Ljubljani

\section{POVZETEK}

Ni vseživljenjskega izobraževanja brez izobraževanja starejših. Tretje obdobje traja tri do štiri desetletja. Družba vseh generacij zahteva dejavno starost. Ustanovitev Slovenske univerze je dokazala, da se ljudje lahko učijo z radostjo in da jim je učenje način življenja. Primarna motivacija starejših je vplivala na motivacijo za izobraževanje otrok in vnukov. Spremenila sta se miselnost in odnos do izobraževanja pri preostalih generacijah. Za nove izzive in nove dejavnosti se starejši morajo pripraviti. Izobraževanje jih lahko usposobi za drugo kariero, za to, da odkrijejo, preizkusijo in izrazijo svoje še neuresničene talente in skrite želje, ter za to, da se lotijo neke nove dejavnosti (pridobitne ali prostovoljne). Poznamo tri različne publike učencev. O njih poročajo mentorji z izkušnjami poučevanja $v$ šoli, pri izobraževanju odraslih na ljudskih univerzah ali v izobraževalnih centrih in sedaj na univerzi za tretje življenjsko obdobje. Šolarji so nezainteresirani za učenje in razvijajo vzporedne strategije, da pridejo do ocen, učitelju prepuščajo odgovornost, da jih nauči, ponavljajo se sekundarni motivi (ocene). Odrasli so motivirani, a jih prehitevajo druge obveznosti in pritiski, kar jim učinkovitost učenja zmanjšuje. Starejši so predani izobraževanju, živijo za svoje učenje in spodbujajo mentorja $k$ še bolj intenzivnim oblikam izobraževanja. Hočejo znanje in so primarno motivirani.

Ključne besede: vseživljenjsko izobraževanje, starejši, mladi, slovenska univerza za tretje življenjsko obdobje

$\mathrm{D}$ ve desetletji in pol opazovanja in spremljanja prakse izobraževanja starejših nam je postreglo s kopico pomembnih spoznanj. Med drugim smo odkrivali, kakšna je motivacija starejših za izobraževanje in kakšne premike je pojav povzročil pri motivaciji za izobraževanje preostalih generacij.

Tudi v naši družbi smo sprejeli princip vseživljenjskega izobraževanja. Kako naj bi ga uresničevali v praksi, če ne bi imeli možnosti za izobraževanje tudi ljudje v zadnjih treh ali štirih desetletjih življenja? Vseživljenjskega izobraževanja ni brez izobraževanja starejših. Vedno večjo skrb posvečamo izobraževanju zapornikov, da ne bi v času prestajanja kazni preveč zaostali za razvojem okolja in se ob povratku v družbo ne bi več znašli. Ista skrb velja za invalide ali osebe $z$ dolgotrajnejšimi obolenji. $\mathrm{Na}$ Nizozemskem že več časa v skrajnih primerih uveljavljajo tako imenovano patronažno izobraževanje, ko mentor prihaja k učencu na dom (invalidi, bolniki, ljudje $\mathrm{v}$ visoki starosti 
ali v četrtem življenjskem obdobju). Današnje pravilo preživetja je za vsako ceno omogočiti vsakemu pot do znanja, sicer ga morajo preživljati in zanj skrbeti drugi. Ljudje brez znanja živijo kot odvisniki, niso samozadostne osebe. Generacija starejših ljudi bo povečala svojo samozadostnost, vitalnost in vpetost $\mathrm{v}$ družbo, če bo sproti sledila novim znanjem. Zmanjšalo se bo število »odvisnikov « in s tem breme preostalim generacijam. Če si bodo znanje delili mlajši, odrasli srednje starosti in starejši, se bodo povečale možnosti za medgeneracijsko sodelovanje. Dejavna starost razbremeni preostale generacije.

Masa ljudi v neki družbi, ki niso samozadostni in jim ne uspeva več dohitevati novih pogojev dela in življenja, se lahko nevarno poveča. Zmanjka dovolj usposobljenih, ki bi jih preživljali. Danci se zavestno sprašujejo: kdo bo preživljal osebe brez ustrezne izobrazbe? Temu primerno urejajo izobraževalno politiko in zakonodajo. Tudi azilante prisilijo, da končajo vsaj višjo šolo. Potem imajo možnost, da jim dovolijo ostati v njihovi državi.

\section{POLITIČNE IN SOCIALNE RAZ- MERE V ČASU, KO SE JE PORA- IALA SLOVENSKA UNIVERZA ZA TRETJE ŽIVLJENJSKO OBDOBJE}

Začetki slovenske univerze za tretje življenjsko obdobje segajo v čas, ko sta bila šolstvo in izobraževanje odraslih pod velikim pritiskom politične ideologije. Ta je družbeno vlogo izobraževanja skrčila na usposabljanje ljudi za poklicno delo. Prvi študijski krožek Univerze za tretje življenjsko obdobje je začel delovati (1984), ko je bila srednja šola v Sloveniji že reformirana, saj je leta 1981 Komite KPJ uvedel usmerjeno izobraževanje - usposabljanje mladih za ozke delovne funkcije. Ukinjene so bile vse gimnazije, prepovedan je bil uvoz tuje literature in učenje tujih jezikov je postalo redkost.

Sekundarni motiv, zakaj naj bi se mladi šolali, je bil politično določen. Izobraževanje naj bo podrejeno delu. Šolska reforma usmerjenega izobraževanja je delovala pod prisilo in po diktatu od zgoraj iz najvišjih političnih vrhov. V tem sta šola in izobraževanje posredno dobila tudi veliko priznanje, ker so ji politiki pripisovali velik pomen, s tem ko je bilo določeno, naj o izobraževanju odloča le najvišje politično telo v takratni zvezni državi. Politiki na republiških ali še nižjih nivojih (okrajih, občinah) niso imeli nobene možnosti, da bi posegom v šolstvo ugovarjali ali se jim uprli. Usmerjeno izobraževanje je bilo izvedeno enoznačno pod taktirko nekaj politikov. Stroki so bile odvzete vse možnosti vplivanja, razen nekaj strokovnjakov, ki so se koristoljubno pomešali med politike. Tudi učitelji in starši niso imeli vpliva na šolstvo. Javno mnenje se ni upoštevalo.

Pritiskom na izobraževanje, povečani politični kontroli in ukinjanju programov se ni moglo izogniti niti izobraževanje aktivnega dela prebivalstva, zaposlenih in preostalih odraslih. Izraz »izobraževanje odraslih« so politiki (s hrvaškim ministrom za šolstvo Stipetom Šuvarjem na čelu) preprosto ukinili. Nenadoma je izraz izginil iz časopisja in preostalih medijev. Nadomestili so ga $\mathrm{z}$ »izobraževanjem ob delu«, »izobraževanjem iz dela« in »izobraževanjem

Kot za druge velja to tudi za starejše. Na rob družbe jih najbolj potiska neznanje. Družbeno izločeni, izobčeni in tujci v svojem okolju se počutijo starejši, ko slišijo razgovore preostalih generacij in neznane izraze: elektronska pošta, blog, facebook, internet, skype in druge. Tujci postanejo v svojem okolju ob pogledu na neznane elektronske naprave; pazijo, da se jih ne dotaknejo, da jih ne bi pokvarili. In vendar bi z malo znanja prav naštete stvari napravile njihovo življenje veliko bolj prijazno, človeško in bi jih celo navduševale, če bi jih poznali. V opisanih razmerjih iščemo globoke korenine današnjih družbenih motivov tudi za izobraževanje starejših. 
Danes vemo, da nas je petnajst let po usmerjenem izobraževanju čakal prehod v informacijsko družbo ali družbo znanja. Pri sedanjem velikem pomanjkanju izobraženosti in znanja šele ugotavljamo, kako genocidno je delovala reforma usmerjenega izobraževanja. Pomembno je, da imamo pred očmi, v kakšnih razmerah se je porajala Slovenska univerza za tretje življenjsko obdobje sredi osemdesetih let. Lahko bi rekli, da je bilo to najtemnejše obdobje v zgodovini našega šolstva in izobraževanja odraslih. Motivacija za izobraževanje je bila zunanja, predpisana, enoznačna: za delo. Človek se je lahko učil le to, kar je potreboval za delovno mesto. Znanje po kapljicah, toliko, da omogoča primerno izkoriščanje ljudi, in nič več. Nobene širine znanja, razgledanosti, miselnih sposobnosti in gojenja kritike in samokritike. Samo ozko naravnano usmerjeno šolstvo in funkcionalno usposabljanje odraslih. Funkcionalno je bila zelo popularna in cenjena beseda. Poudarjala je, da naj se delavec nauči le to, kar ozko od njega zahteva stroj. In nič zraven, levo in desno, po svoje ali učenje po željah človeka.

na delu«. To je bil samo del novo nastalega popačenega jezika, ki so ga politiki birokratsko uvajali brez možnosti ugovora. Po državi so zaprli osnovne šole za delavce, ker nevarna splošna izobrazba »ni bila več potrebna«. Ljudje so živeli pod pritiskom, da sta izobraževanje in šolanje uporabni le, če sta podrejeni poklicnemu delu. Stipe Šuvar je napisal knjigo »Združeno delo in šola« in takoj je bila prevedena $\mathrm{v}$ vse jugoslovanske jezike. Kultura in splošna izobrazba sta bili v takih razmerah nepotrebna navlaka ali celo sovražna dejavnost.

Morda je bil to zadnji krč države, ki drvi v prepad. Morda so vodilni politiki videli rešitev v še večji diktaturi in povečanju političnih pritiskov na ljudi. So upali, da bodo z reformo usmerjenega izobraževanja in ukinjanjem izobraževanja odraslih obvladali mladino in odrasle? Otroke so usmerjali v šole po predpisanih kvotah, ne glede na to, da jih ta šola ni zanimala. S tem so negirali osebne motive otrok za izobraževanje. Šolstvo je delovalo po ukazu. Izgovor je bila zaostala industrijska proizvodnja, po kateri naj bi oblikovali tudi učne načrte. Sistem, ki deluje na »moraš«, se ne zanima za motive učencev.

\section{PRI IZOBRAŽEVANJU ŠOLARJEV IN ODRASLIH PREVLADUJEJO SEKUNDARNI MOTIVI: OCENE IN SLUŽBA}

V šolstvu prevladujejo sekundarni ali zunanji motivi. Otrok se uči: zaradi ocen, da bo izdelal razred, da ga starši ne kregajo, da bo pisal test pozitivno. Vedoželjnost otroka, sla po odkrivanju neznanega kot naravna lastnost vsakega človeka ali primarna motivacija, tako zelo bujna $\mathrm{v}$ predšolskem obdobju, postopoma zbledi pod pritiski sekundarnih motivov šolskega ustroja. Šolar pozabi, da se uči zase, da je učenje lahko užitek in prijetno doživetje brez prisile.

V skrbno načrtovanem šolskem pouku si sekundarni motivi podajajo roke. Sekundarni motivi (ocene, kontrolka, izpit, roditeljski sestanek) delujejo samo omejen čas. Ko nevarnost preneha, ugasnejo. Na poti so že drugi, novi zunanji motivi, da bi prisilili učence $\mathrm{k}$ učenju. Učijo se zaradi zunanje prisile. Postopoma pozabijo, zakaj se učijo, in vedoželjnost zbledi. Učenje jim postane odvečna nadloga in jim ni v veselje, kot je bilo v predšolski dobi (Krajnc, 1982).

Svojim interesom in osebnim motivom se bolj približajo, ko izbirajo študij na univerzi. Čutijo, da imajo več svobode. Če je študent lahko izbral študij, ki ga veseli, se bo vedoželjnost začela spet prebujati in »študiral bo na lastni pogon«. Po ugotovitvah Millerja se vedoželjnost vrača pri visokoizobraženih ljudeh, znanstvenikih in umetnikih. To pa je tanek sloj prebivalstva srednje starosti (Krajnc et al., 1994).

V osemdesetih letih prejšnjega stoletja, ko je nastajala Univerza za tretje življenjsko obdobje, so bili tudi zaposleni pod pritiski ideologije, ki je malikovala produktivnost in stroj. Človek naj bi se usposabljal, da bo lahko stregel stroju 
in bo čimbolj produktiven. Pri odraslih je bilo takrat še bolj poudarjeno, da je služba edini (sekundarni) motiv za izobraževanje in usposabljanje. Vsako drugo nagnjeVedoželjnost je naj-
večja pri visoko-
izobraženih ljudeh,
znanstvenikih in
umetnikih. nje so zavrnili kot nesmiselno. Izobraževanje za službo je bil splošen ideološki motiv. Ta sekundarni motiv pa je postopoma prodrl tudi v miselnost ljudi in ti so smisel izobraževanja povezovali le s službo. Po raziskavah sodeč je vedoželjnost poganjala le nekaj odstotkov odraslih. Prisotna je bila pri ljudeh na visokih vodilnih položajih, umetnikih in znanstvenikih (Krajnc, 1982).

\section{SOCIALNI STEREOTIP O STAREJŠIH JE IZOBRAŽEVANJE IZKLJUČIL KOT NEMOGOČE IN NEPOTREBNO}

Vrnimo se v leta nastajanja Univerze za tretje življenjsko obdobje: od leta 1984 naprej. Pojav se je zdel ljudem precej nenavaden. Niso vedeli, ali naj ga jemljejo kot šalo ali kot resno ponudbo, ali naj temu verjamejo ali ne. Prve poskuse so ljudje sprejeli

Izobraževanje za službo je bil ideološki motiv. s presenečenjem, zdeli so se jim neverjetni. $Z$ vprašanji so preverjali, ali res nameravamo »to« početi. Izobraževanje starejših, ki smo ga uvajali, je bilo v nasprotju z globoko usidranim socialnim stereotipom o starejših. Najbolj do izraza sta prišli dve stališči iz socialnega stereotipa o starejših:

- starejši nimajo več sposobnosti za učenje;

- za starejše izobraževanje nima nobenega smisla, ker niso več v službi.

Možnost, da bi se lahko še izobraževali, se je zdela starejšim prijetno odkritje. Končno jih je nekdo povabil »nazaj med ljudi«. Poleg prijetnih občutkov pa so se pri starejših porajali tudi strahovi in zavore. Zato smo v začetku, prva študijska leta, opazili, da študentke po- gosto prihajajo na Univerzo v parih, ker niso imele dovolj poguma, da bi prišle posamično. Strah so premagale, če so prišle skupaj s sosedo ali prijateljico.

Negotovost in strah jim ni vzbujal samo nov pojav: izobraževanje za starejše. Porajalo ga je tudi novo vstopanje $\mathrm{v}$ javnost, potem ko so se že po upokojitvi naučile živeti v samoti, izločene iz družbe.

\section{ELITA ŠTUDENTOV PRVIH GENERACIJ JE UTRJEVALA POT UNIVERZI ZA TRETJE ŽIVLJENJSKO OBDOBJE}

Prva leta (sredi osemdesetih let prejšnjega stoletja), ko se je Univerza za tretje življenjsko obdobje v našem okolju šele uveljavljala, smo $\mathrm{z}$ analizo razgovorov in opazovanjem odkrili določeno tipologijo vključevanja starejših $\mathrm{v}$ izobraževanje. Vpisovali so se:

- ljudje, ki so imeli prej v službi visok, vodilni položaj in so še vedno razpolagali z višjo družbeno samozavestjo (direktorji podjetij, ravnateljice šol, vodje lekarn, računovodkinje, vodje pisarn, političarke),

- ljudje z visoko stopnjo osebnostnega razvoja (samostojni, z visoko samozavestjo, pozitivno samopodobo, samoiniciativni, ambiciozni, ustvarjalni in vedoželjni),

- ljudje z višjo ali visoko stopnjo izobrazbe, formalno opravljeno ali pridobljeno zaradi zahtevnosti dela v službi.

Naštete kategorije ljudi so imele to prednost, da so bile sposobne braniti svoje želje, nagnjenja in interese, se upreti javnemu mnenju o starejših in hoditi svojo pot po lastni odločitvi, nagnjenjih in sposobnostih. Stereotip o starejših so zavrgle in se niso ozirale na to, kaj bodo drugi mislili ali rekli. Vsaka od študentk je hodila svojo pot, se zagrizla v učenje in kmalu tudi slavila svoje uspehe.

Prav pod vplivom tega, kdo se je na začetku odločal za študij na Univerzi za tretje življenjsko obdobje, so v javnosti leteli na nas pri- 
pombe in očitki, da se ukvarjamo samo z elito, da je naša dejavnost »odtrgana od ljudi in namenjena samo tistim na vrhu.«V nasprotju z očitki smo na Univerzi za tretje življenjsko obdobje že od samega koncipiranja dalje poudarili, da je to »študij odprtih vrat « in sprejme vsakega starejšega, ki se želi izobraževati ne glede na katerekoli osebne karakteristike, kot so: starost, spol, izobrazba, veroizpoved itn. Zagovarjali smo in še danes se ravnamo po teh principih, da naj bo študij svoboden in dostopen vsakemu (»open access to education«). Nasprotujemo zaprtemu delovanju šolskega sistema, ki s preštevanjem točk izloča mlade in jim zapira možnosti za nadaljevanje šolanja. Odprt dostop do izobraževanja za vse ljudi (tudi za starejše) sta glavno pravilo današnjega časa in edina oblika preživetja. Znanje je za življenje, kot je kisik za dihanje.

Elita ima pomembno družbeno vlogo. S svojo prodornostjo kot klin odpira $\mathrm{v}$ družbi nova področja in pripravlja pot za tiste, ki ji sledijo. To se je zgodilo tudi na univerzi za tretje življenjsko obdobje. Prvi so prestali preizkus, uspeli pri študiju in dokazali drugim, da se starejši brez težav lahko učijo. Spreminjalo se je postopoma javno mnenje in tudi strah pri preostalih starejših pred novim in neznanim je popuščal. $\mathrm{V}$ vpisanih generacijah naslednjih študijskih let se je število študentov s srednjo šolo najbolj povečalo in končno prevladalo. Med študentkami in študenti so bili tudi ljudje samo z osnovno šolo. Opogumili so se in prihajajo posamično, brez spremljevalke. Med novimi obrazi odkrito iščejo nova prijateljstva. Če so se predolgo zasedeli v svoji samoti, ločeni od ljudi, potem raje prej pokličejo po telefonu in še enkrat preverijo, ali se res lahko vpišejo, kateri študijski krožki imajo še prosta mesta in kam natanko naj pridejo. Danes je skoraj samoumevno, da se ob upokojitvi vpišeš na Univerzo za tretje življenjsko obdobje. Pojav je postal vsakdanji in navaden.

\section{ŠTUDENTJE UNIVERZE ZA TRETJE ŽIVLJENJSKO OBDOBJE OBUDIJO VEĆNO RESNICO, DA SE ČLOVEK UČI ZASE. VEDO- ŽELINOSTI KOT PRIMARNA MO- TIVACIJA ZA IZOBRAŽEVANJE}

Strokovnjaki smo bili v času reforme usmerjenega izobraževanja nemočni, da bi vplivali na kvaliteto šolstva ali izobraževanja odraslih. Zato smo iskali nova področja, kjer bi lahko razvili izobraževanje po meri človeka. Iskali smo pot $\mathrm{k}$ bolj humanim in sodobnim konceptom izobraževanja, naravnanim na učenca (»learner centered education $\ll$ ), kot smo jih srečevali na številnih mednarodnih konferencah. Odločili smo se, da tudi doma nekaj tega uresničimo. Nekaj, kar bi bilo čim dlje proč od usmerjenega izobraževanja, in učenje, ki ne bi bilo podrejeno samo službi.

Po zgledu mreže francoskih univerz za tretje življenjsko obdobje in evropskega zakona o obveznem usposabljanju ljudi za upokojitev smo začeli oblikovati koncept slovenske univerze za tretje življenjsko obdobje. (Krajnc et al., 1992). Upokojenci so bili tako odpisani del prebival-

Široko gledano motivacijo za izobraževanje mladih in ljudi srednje starosti poganjajo predvsem zunanji, sekundarni motivi, in sicer dva temeljna motiva: šolska mladina se »mora« učiti zaradi ocen in točkovanja, aktivni del prebivalstva zaradi službe. Zato se je tem generacijam zdelo izobraževanje starejših nesmiselno, saj ne hodijo več v šolo in tudi v službo ne več. Zakaj bi se potem človek še moral izobraževati. Pod pritiski navedenih dveh prevladujočih sekundarnih motivov so ljudje pozabili na osebno vedoželjnost, primarno motivacijo in na to, da karkoli že se človek uči, se uči predvsem zase, za svoj razvoj, da poteši svojo radovednost in odkriva neznano. 
stva in takrat nikogar od politikov niso zanimali. $\mathrm{V}$ javnosti kot da niso obstajali. In prav ta izrinjenost starejših iz družbe jim je prinašala pomembno svobodo. Lahko so živeli in mislili po svoje, se sami odločali, sledili svojim interesom, sebi. Na njih politični pritiski in kontrola niso bili usmerjeni. Tu je bil socialni prostor, v katerem, se je lahko zgodilo nekaj novega, nekaj drugačnega od kalupa diktature.

Tudi strokovnjaki, ki smo začeli snovati Univerzo za tretje življenjsko obdobje, smo imeli svoje jasne motive. Želeli smo dokazati, da je izobraževanje brez prisile možno, da je izobraževanje kot radost naravni odsev človekove vedoželjnosti in da je izobraževanje $\mathrm{v}$ današnji družbi pomemben del vsakega človekovega obdobja, tudi tretjega. Motivacija za izobraževanje ni vedno enaka in treba jo je sproti krepiti in vzdrževati. To pa $\mathrm{v}$ tesnih stikih male skupine $\mathrm{z}$ mentorjem, animatorjem in tudi študentov ni težko. Učenje $\mathrm{v}$ malih skupinah dobi posebne kvalitete in spodbuja motivacijo kot vedoželjnost. Dovoli, da vsak študent pride do izraza. Motivacija za izobraževanje je zelo osebna zadeva in je ne moremo posploševati za celo študijsko skupino.

Tudi nagibi, zakaj so se starejši vključili v določen študijski krožek, so zelo različni. Vzemimo krožek za medosebne odnose in transakcijsko analizo. Ena od študentk bi rada imela čim boljše odnose $\mathrm{z}$ ljudmi. Živi sama in išče odnose bližine med sosedi in znanci. Druga študentka bi rada prebolela travme svojega odnosa $\mathrm{z}$ mamo, ki so jo bremenile vse življenje. Sedaj bi se jim rada še posebno posvetila in dosegla svoj mir. Naslednja študentka meni, da snaha ne ravna prav $\mathrm{z}$ vnuki, in pri tem zelo trpi. Rada bi ji na strokoven način to dopovedala. Ena od študentk je vdova. Po moževi smrti »je zadihala«. Začutila je, da je bolj sproščena, ima veselje do življenja in delo jo osrečuje. Išče, kaj je bilo narobe $\mathrm{v}$ njunem odnosu $\mathrm{z}$ možem: ga je razumela, je on razumel njo?

Tudi osebna, primarna motivacija se prelije $\mathrm{v}$ bolj konkreten motiv in jasno željo ali interes, cilj, ki bi ga radi z znanjem dosegli. Ta cilj je naš oseben in ne zunanji.

Študij na Univerzi poteka brez prisile. Kljub temu osipa skoraj ne poznamo. Morda se katera od študentk premisli že na začetku študijskega leta, ko ugotovi, da je prišlo do nesporazuma, vpisala se je na nekaj drugega, kot je pričakovala, in gre drugam. Študentje na srečanjih študijskih krožkov zelo redko manjkajo. Mora se nekaj posebnega zgoditi (bolezen, pogreb, potovanje v tujino), da jih ni. Enako nimajo radi, da jim srečanje odpade, da mentor odpove. Študij je velika medsebojna obveza. Če mentor že mora odpovedati, potem je potrebno, da pove dovolj zgodaj, in tudi pojasni razlog. Primerjajmo ta odnos starejših do njihovega študija $\mathrm{z}$ odnosom šolarjem! Zavriskajo, ko jim kaj odpade.

Znane so nemške raziskave, ki so dokazale, da se primarna motivacija za izobraževanje, vedoželjnost vrača pri starejših ne glede na socialni sloj. To, kar ima generacija srednje starosti odraslih le v elitnem sloju (ohranjeno vedoželjnost), imajo starejši $\mathrm{z}$ različno predhodno izobrazbo. Tudi manj izobraženi starejši prodirajo s svojo vedoželjnostjo $\mathrm{v}$ formalne in neformalne oblike izobraževanja, ker preprosto hočejo vedeti, odkrivati neznano. Ugotovitve Millerja so se potrdile tudi pri nas že kar na začetku. (Miller, 1071).

Veselje do učenja se krepi v tesnih stikih med ljudmi. V organizacijsko shemo Univerze smo vpeljali študijske krožke (od 8 do 12 ljudi) kot male skupine. Dinamika in intenzivnost medosebnih odnosov sproti poživljata učenje vsakega od članov. V veliko spodbudo so dogajanja v mali skupini močan motiv tudi za mentorja. Poleg mentorja vodi dogajanje v krožku tudi animator, eden od študentov. Ta skrbi za stik študijskega krožka z glavnim sedežem Univerze za tretje življenjsko obdobje. 
Vplivi izobraževanja starejših na motivacijo za izobraževanje otrok in zaposlenih so bili v našem okolju vidni. Otroci so si vzeli čas, da so se poleg šole prostovoljno učili še nekaj, kar jih zares zanima. Zaposleni so iskali možnosti, da si po svoje organizirajo kako učenje kot oseben učni projekt po neformalni poti. V našem socialnem in kulturnem okolju se je začelo prebujati pričakovanje, da se človek uči zase in z radostjo, da je učenje prijeten doživljaj.

Dedki in babice so dokazali, da jim je izobraževanje radost in da se učijo zase, ker so radovedni, ker preprosto hočejo nekaj znati. Odnos starejših do izobraževanja je dal misliti tudi njihovim otrokom (zaposlenim) in vnukom v šolah. Najprej jim niso verjeli. Čudili so se temu, da babica hodi na Univerzo, ko se ji pa vendar ni treba več učiti. Nihče je ne sili. »Ampak meni je tako lepo. Hočem to vedeti, « so bili odgovori. Ker se je študij na Univerzi nadaljeval, je spreminjal miselnost in odnos do izobraževanja preostalih generacij v družini. Tudi hčerka naše študentke ali sin, oba obremenjena s službo, sta pomislila, kako lepo bi se bilo naučiti nekaj, kar te veseli, nekaj osebnega, čisto zase. Morda pa res ni smisel izobraževanja samo služba. Postopoma so dopuščali možnost, da je izobraževanje lahko tudi radostno in zelo osebno.

\section{TRI IZOBRAŽEVALNE PUBBLIKE GLEDE NA RAZLIKE V MOTIVA- CIJI ZA IZOBRAŽEVANJE}

Posebno pozornost smo posvetili na Univerzi mentorjem, ki poučujejo ali so poučevali v redni šoli, so bili izobraževalci na ljudskih univerzah ali drugih centrih za izobraževanje odraslih in so sedaj ali vzporedno mentorji v študijskih krožkih na Univerzi za tretje življenjsko obdobje. Prosili smo jih, da nam glede na izkušnje opredelijo vsak tip izobraževalne publike. Opredelitve več mentorjev so se zelo približale.

Vsako publiko učencev so doživljali na svoj način in jo gledajo kot posebno entiteto.

Učenci $v$ šoli so nezainteresirani in se učijo pod prisilo in pritiski učitelja. Odgovornost in skrb za znanje prepuščajo učitelju. Z naveličanostjo spremljajo novo učno snov. Izražajo apatičen odnos do znanja. V želji, da bi si pomagali do boljših ocen, razvijajo razne strategije, z njimi naj bi na najlažji in najkrajši možni način prišli do ocene. $Z$ izobraževanjem so zasičeni in do šole imajo večinoma odklonilen odnos. Ta se ponovi tudi do dobrih učencev, ker je trud za znanje, učenje sramota in šibkost »piflarjev«. Skoraj sramota. Zato se v razredu vsevprek hvalijo, kako se niso nič učili. »Treba se je znajti«, je nenapisano pravilo, in se otresti nadležne učiteljice in učenja. Učitelji so izražali slabe občutke v razredu, kot bi »site silili jesti«, kot se je izrazila ena od mentoric. Druga je opisala učence v razredu kot »težko, svinčeno breme, gmoto, ki jih le s težavo za trenutek navduši za kako temo«.

Drugačna publika so bili odrasli. Imeli so močno željo, da se nekaj naučijo na primer angleščine, knjigovodstva, računalniškega programa itn. Na izobraževanje so prišli odgovorno in $\mathrm{z}$ jasnim sekundarnim motivom, zakaj to znanje potrebujejo. Zavzeti so bili in pripravljeni za učenje. Miselno zbranost so jim motili preostale obveznosti, pritiski raznih odgovornosti (sestanek, razgovor s šefom ob napovedani uri, datum za oddajo poročila, otroci v vrtcu, zidava hiše, popravilo gospodinjskega aparata, srečanje športnega kluba, dogovor s prijateljem itn.). Odrasli so motivirani za izobraževanje, čutijo potrebe po znanju, vendar so pod močnim pritiskom drugih dogodkov in obveznosti. Zato njihovo učenje ni vedno uspešno, vsekakor manj, kot bi po motivaciji pričakovali. Zagozdeno je med veliko dnevnih opravkov in naglim tempom dela in življenja. Kljub motivaciji na seminarje ne prihajajo redno, zamujajo ali se težko zbe- 
rejo, odidejo pred koncem. Težko najdejo pravi čas za učenje. Mentorji so opisovali razmere v učnih skupinah odraslih. Raziskati bi bilo treba še lestvico glavnih vrednot učencev v skupinah. Kaj jim je najpomembnejše $v$ dani situaciji in $V$ študijskem krožku vladajo medosebni »odnosi bližine«.

kje je osebno pri njih znanje kot vrednota. Ali mu dajejo prednost pred preostalim?

Mentorji so opisovali še značilnosti tretje publike učencev: starejše v študijskih krožkih. Študentje so motivirani za učenje, živijo za to. Izobraževanje jim postane način življenja. Navezani so na mentorja in mu zaupajo. Radi se imajo tudi med seboj in to na razne načine pokažejo. $\mathrm{V}$ študijskem krožku vladajo odnosi medsebojnega zaupanja. Zelo so zavzeti za to, da bi se naučili. S predlogi in vprašanji zasipavajo mentorja še naprej od načrtovanega. Srečanja študijskih krožkov popestrijo s primeri in odkritji, ki so jih pridobili na zadnjem srečanju. Očitno izobraževanju posvetijo veliko časa. Učenje se po lastni želji in odločitvi posamezne študentke nadaljuje individualno, potem ko se študijski krožek za določen teden že razide. »Delo v študijskih krožkih mi je velika spodbuda in osebna nagrada, ker vidim, da so vedoželjni in se želijo naučiti«. Tudi preobremenjeni mentorji nadaljujejo delo na Univerzi, ker pravijo, da jih psihično kot mentorje zelo nagrajuje. »To delam za svojo dušo, ono drugo za denar.« Zanimiva primerjava treh učnih publik nam je torej odkrila posebnosti izobraževanja $\mathrm{v}$ posameznih življenjskih obdobjih.

\section{IZOBRAŽEVANIE STAREIŠIH NI SAMO SEBI NAMEN}

Glaven motiv starejših je vedoželjnost. Vendar je izobraževanje socialni odnos in teži k samopotrjevanju in konkretnim ciljem, kaj nekdo z znanjem lahko počne in dokaže drugim. Starejši navajajo, da jih izobraževanje veseli, ker:

- bi radi postali nekaj novega, to, kar še niso, radi bi odkrivali sebe, svoje talente;
- bi radi pojasnili toliko neznank v svetu, ki jih obdaja, radi bi bolje razumeli vesolje, naravo, računalništvo, umetnost, druge ljudi in sebe itn.;

- bi radi razširili in povečali svoje življenjske možnosti, si pridobili nove spretnosti, izurili nekatere sposobnosti.

V strokovni literaturi navajajo več področij in načinov uporabe znanja, ker se življenjski pogoji ljudi razlikujejo od njihovih želja. Nekateri se počutijo zelo zasičeni s prejšnjo kariero do upokojitve. Po upokojitvi si želijo, da načnejo nekaj povsem drugega in na novo. $\mathrm{Za}$ to potrebujejo znanje. Čim bolj so izobraženi, tem višje cilje imajo tudi v novi karieri. Avtorji govorijo o »drugi karieri«. Ti starejši se vpišejo na redne univerze ali znanje osvojijo $\mathrm{v}$ nizu seminarjev in drugih formalnih oblik študija.

Trideset let v tretjem življenjskem obdobju jim daje dovolj čas za učenje in drugo kariero.

Drugim je motiv za učenje, da uresničijo svoje talente, preizkusijo osebne zmožnosti, izpolnijo skrite želje. Osredotočijo se na neko dejavnost, na primer: igranje glasbenega instrumenta, slikanje, pisanje pesmi, sadjarstvo, delo $\mathrm{z}$ ljudmi $\mathrm{v}$ stiski in podobno. $\mathrm{V}$ tretjem življenjskem obdobju ljudje več razmišljajo o sebi. Manj je zunanjih odgovornosti in prisil. Imajo svobodo, da prisluhnejo sami sebi, in na dan pridejo tudi najbolj skrite želje. Ti motivi podpirajo zlasti samopotrjevanje in samouresničevanje osebe. Pokojni gospod Miro Kranjec iz Sežane, upokojeni računovodja v izvoznem podjetju, je po upokojitvi postal slikar. Slikal in razstavljal je 25 let. Ob neki priložnosti je dejal: »O smrti ne razmišljam. Živim in ustvarjam: ko bo prišla, me bo našla pripravljenega. Izpolnila se mi je želja, ki sem jo od otroštva nosil v sebi, da bi postal slikar.«

Motivi za izobraževanje so povezani še z posameznimi pridobitnimi in prostovoljnimi dejavnostmi, kot so: turistično vodenje, pripovedovanje pravljic, oskrba bolnikov, knjigovodski servis, vrtnarjenje, gostinska ponudba, sad- 
jarstvo, tiskarstvo, varstvo predšolskih otrok, in še bi jih lahko naštevali. Pri teh starejših je izobraževalni cilj vedno povezan $\mathrm{z}$ akcijskim ciljem. Sproti preverjajo uporabnost znanja in iščejo podrobnosti. K formalnim oblikam študija v krožkih dodajajo še razne obiske, oglede, vaje, prakso in poskusno delo z ljudmi, ki to že znajo.

Uporaba znanja je končni cilj učenja. Dejavnost in z njo samopotrjevanje, socialna pripadnost in povezovanje $\mathrm{v}$ nove skupine. Nova znanstva in prijateljstva, če imaš dejavno starost, se spontano porajajo.

Napačen je pomislek mlajših, da starejši hodijo na Univerzo, ker jim je doma dolgčas in iščejo stike z ljudmi. Stiki z ljudmi so za vsakega pomembni in so eden od motivov starejših. Nikakor pa ne glavni. Če jih ne bi gnala $\mathrm{k}$ študiju vedoželjnost, se ne bi tako zavzeto borili za znanje.

\section{LITERATURA}

Krajnc et al (1992). Kako smo snovali Slovensko univerzo za tretje življenjsko obdobje. Ljubljana: Univerzum.

Krajnc et al.(1994): Študentom na pot. Univerza v Ljubljani, Center za razvoj univerze, Ljubljana.

Krajnc, Ana (1982): Motivacija za izobraževanje. Ljubljana: Delavska enotnost.

Ramovš, Jože (2008). »Družba za vse generacije: izzivi in priložnosti«. Kakovostna starost. Vol. 11, št 1, 51-53.

Towards a European Society of all Ages. Brusel: AGE, 2006.

White Paper on Education and Training. Teaching and Learning Towards the Learning Society. Evropean Parliament, 1996.

Krajnc, Ana (2001). Kako doseči polno življenje po upokojitvi. Ljubljana: Slovenska univerza za tretje življenjsko obdobje.

Skupina avtorjev (2007). Učenje po meri starejših ljudi. LENA. EU projekt, Ljubljana: ZDUS.

Skupina avtorjev (2008): The Legacy of Learning. Strasclyde University, Glasgow.

Skupina avtorjev (2007). Learning in Later Life. NIACE, Leicester. 